\title{
ORIGINAL ARTICLE \\ New record of Centronycteris centralis Thomas, 1912 (Chiroptera: Emballonuridae) from the Chocó Biogeographic Region, with an updated distribution map
}

\author{
Leison Palacios-Mosquera ${ }^{1,}{ }^{*}$, Jilbher Quinto-Mosquera ${ }^{1}$, Jonard David Echavarría-Renteria ${ }^{1}$, \\ Luis Alberto Moreno-Amud ${ }^{1}$, Alex Mauricio Jiménez-Ortega ${ }^{1}$, Paúl M. Velazco ${ }^{2,3}$
}

\author{
${ }^{1}$ Universidad Tecnológica del Chocó, \\ Facultad de Ciencias Naturales, Grupo \\ de Investigación Manejo y Gestión de la \\ Vida Silvestre del Chocó, Quibdó, Chocó, \\ Colombia \\ 2 Department of Mammalogy, American \\ Museum of Natural History, New York, \\ USA \\ ${ }^{3}$ Department of Biology, Arcadia \\ University, Glenside, PA 19038, USA \\ *Corresponding author: \\ lepamo8@gmail.com
}

\begin{abstract}
Emballonurid bats of the genus Centronycteris are rare and poorly represented in scientific collections and in the literature. We report the second record of Thomas's Shaggy bat Centronycteris centralis Thomas, 1912 for the Choco biogeographic region of Colombia and first one for the department of Chocó. This new record fills a large distributional gap of this species in western Colombia and backs the importance of the newly created AICOM Pacurita Chocó-Central where this specimen was collected.
\end{abstract}

\section{INTRODUCTION}

Bats of the genus Centronycteris Gray, 1838 are among the rarest Neotropical Emballonuridae (Simmons \& Handley 1998) and can be distinguished from other emballonurids by their long and soft dorsal pelage which is raw umber to tawny; the venter is paler; uropatagium and fur between the eyes are reddish; wing sacs are absent; plagiopatagium is attached to the metatarsals near the base of the toes. Craniodentally it can also be distinguished from other members of the family: skull presents a flat dorsal profile; postorbital processes are relatively short; sagittal crest is well-developed; basisphenoid pits are large and subdivided by a median septum; and first upper premolars are tricuspidate (Hood \& Gardner 2008). Two species are currently recognized in the genus, $C$. centralis Thomas, 1912 is known to occur from southeastern Mexico (Isthmus of Tehúantepec) southeastward through Panama into South America where it occurs in western Colombia, Ecuador, and eastern Peru; whereas, C. maximiliani (Fischer 1829) is known to occur in northeastern Peru, southwestern Colombia, southern Venezuela, the Guianas, northern and eastern Brazil (Simmons \& Handley 1998, Hood \& Gardner 2008). Although the distribution ranges of both species combined encompass a wide distribution area, they are rare and known from only a few specimens in natural history collections (Arita 1993, Simmons \& Handley 1998, Hood \&
Gardner 2008). Before the review of the genus by Simmons \& Handley (1998), C. centralis was regarded as a subspecies of C. maximiliani, a decision proposed by Sanborn (1936, 1937). However, Simmons \& Handley (1998) more recently found several characteristics in the skull and dentition that supported the recognition of both centralis and maximiliani as valid species.

Morphologically, Centronycteris centralis can be distinguished from $C$. maximiliani by the combination of the following characteristics: rostrum lacking a dorsolateral swelling at the base of the postorbital process (dorsolateral swelling present in maximiliani); nasals not constricted anteriorly, extending beyond the anterior borders of orbit (nasals strongly constricted anteriorly between medially expanded maxillae and terminate at level of anterior borders of orbits in maximiliani); basisphenoid pits not divided into anterior and posterior sections and not protruding into mesopterygoid fossa (basisphenoid pits weakly divided into anterior and posterior sections with anterior section extending forward between pterygoid processes in maximiliani); posterolateral margins of palate with an indentation extending anterior to posteromedial border of palate (posterolateral margins of palate smoothly curved in maximiliani); mandible gracile, depth of ramus at second premolar/m1 juncture approximately equal to twothirds of the height of the second lower premolar (mandible 
robust, depth of ramus at second premolar $/ \mathrm{m}^{1}$ juncture approximately equal to height of the second lower premolar in maximiliani); gap present between $\mathrm{m}^{3}$ and anterior border of ascending ramus of coronoid process, ascending ramus rises at steep angle from body of mandible (gap absent, ascending ramus of coronoid process rises in gentle curve from immediately behind $\mathrm{m}^{3}$ in maximiliani); and maximum crown length of the first upper premolar greater than one-fourth that of the second upper premolar (first upper premolar small, maximum crown length less than one-fourth that the second upper premolar in maximiliani) (Simmons \& Handley 1998, Hood \& Gardner 2008).

In Colombia, Centronycteris centralis is known from several localities, but only one in the Pacific region (Valle del Cauca - Río Anchicayá); (Simmons \& Handley 1998, Castaño \& Corrales 2007, Rodríguez-Posada 2016). Herein we report the second locality of Centronycteris centralis for the Pacific region of Colombia and the first for the department of Chocó, while providing an updated distribution map for the species.

\section{MATERIALS AND METHODS}

The samplings were performed at the Municipality of Quibdo, Department of Chocó (Colombia) during the project "Diversity of insectivorous bats in the rainforest of Chocó Biogeographic". We used mist-nets of 6 and 12 meters at different forest heights with a total sampling effort of 160,928 hour.meter.net. The habitat at the site of capture is predominately a primary tropical rainforest without anthropic intervention, characterized by the following species: Brosimum utile, Calophyllum auratum, Cecropia insignis, Cecropia virgusa, Chrysochlamys floribunda, Chrysochlamys dependens, Couma macrocarpa, Eschweilera sclerophylla, Oenocarpus bataua, Pentaclethra macroloba, Phragmotheca siderosa, Protium apiculatum, Pterocarpus officinalis, Vochysia ferruginea, and several species of Inga, Jacaranda, Pseudolmedia, and Vismia (Quinto-Mosquera et al. 2016). Representatives of each captured bat species were sacrificed following the guidelines of the American Society of Mammalogists for the use of wild mammals in research (Sikes \& the Animal Care and Use Committee of the American Society of Mammalogists 2016). We identified the specimens with the help of the following literature: Simmons \& Handley (1998), Hood \& Gardner (2008) and Reid (2009).

\section{RESULTS}

During the entire duration of the project, 41 insectivorous bats were collected. Amongst them, an adult male specimen of Centronycteris centralis was collected on May 12, 2010 one meter from the ground in one of our sampling sites named Pacurita (540'04" $\mathrm{N}$, 7634'12"W; $113 \mathrm{~m})$. On the night of the capture the temperature was $26.6 \circ \mathrm{C}$ and the relative humidity $99 \%$. The specimen was prepared as a study skin accompanied with a clean skull and was deposited in the Colección Mastozoológica del Chocó, Universidad Tecnológica del Chocó ( $\mathrm{CMCH})$ under catalogue number $\mathrm{CMCH} 987$ (Fig. 1). Other bat species collected at the same locality were: Saccopteryx bilineata (Temminck, 1838); Artibeus lituratus (Olfers, 1818); Artibeus

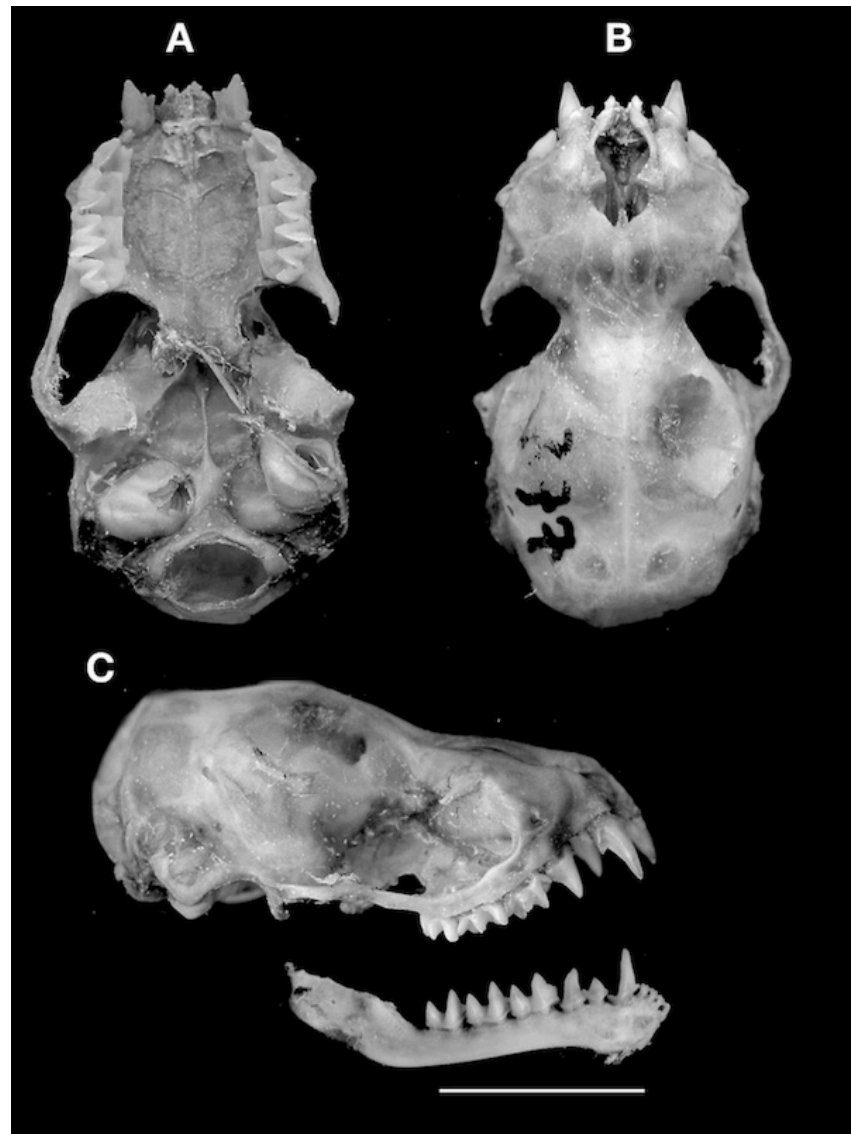

Fig. 1 - Dorsal view of the skull (A), left lateral view of the mandible (B), and dorsal view of the study skin of Centronycteris centralis ( $\mathrm{CMCH}$ 987; adult male). Scale bar $=5 \mathrm{~mm}$.

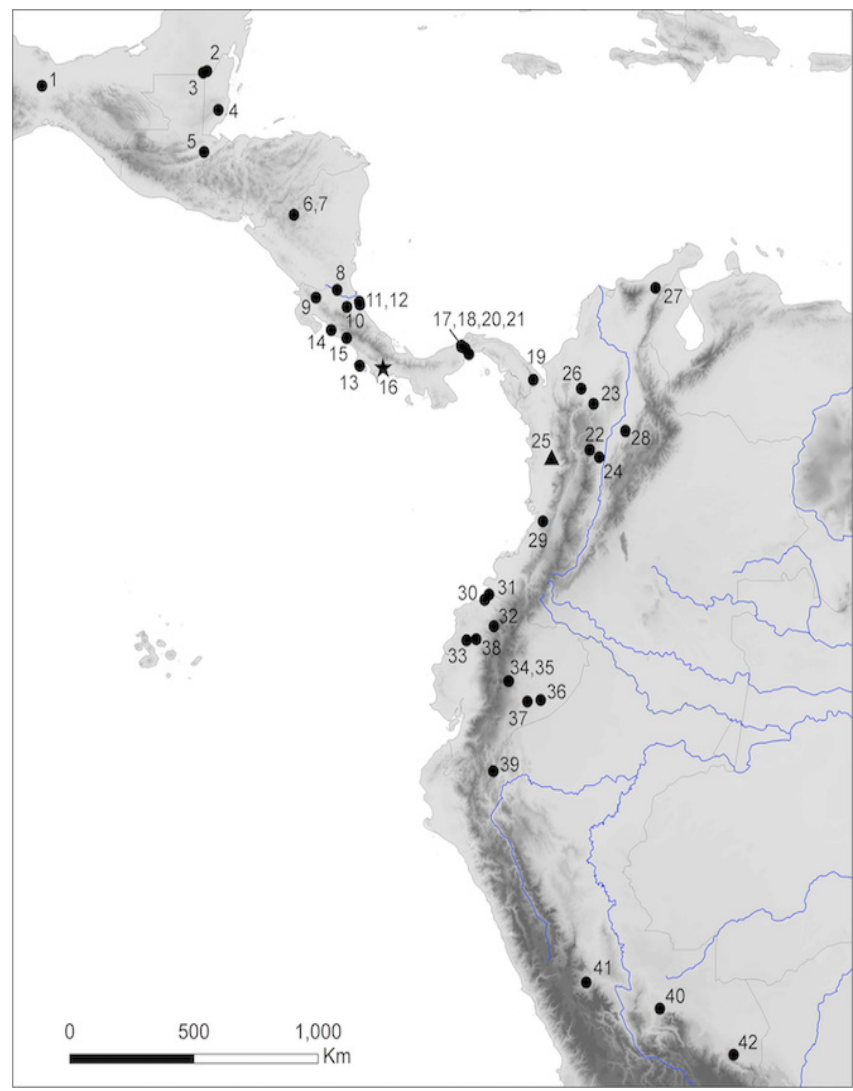

Fig. 2 - Geographic distribution of Centronycteris centralis showing all known collecting localities. The type locality is represented by a star and the new record from the Chocó by a triangle. Names and geographic coordinates of numbered localities are provided in the Supplementary Material. 
Table 1 - External and craniodental measurements of Centronycteris centralis. ${ }^{a}$ Measurements from Simmons \& Handley (1998). bMeasurements from Simmons \& Handley (1998), Hice \& Solari (2002), Woodman (2003), Castaño \& Corrales (2007) and RodríguezPosada (2016).

\begin{tabular}{|c|c|c|c|}
\hline & \multicolumn{3}{|c|}{ Centronycteris centralis } \\
\hline & Males $^{a}$ & CMCH987 & Females $^{\text {b }}$ \\
\hline Weight & $(4.0-5.0) 3$ & 4.5 & $(5.0-7.0) 6$ \\
\hline Total length & $(60.0-78.0) 7$ & 73.0 & (66.0-93.0) 9 \\
\hline Tail length & $(18.0-32.0) 6$ & 17.0 & (17.0-40.0) 9 \\
\hline Hindfoot length & $(7.0-8.5) 8$ & 5.8 & (7.0-9.0) 13 \\
\hline Ear length & $(15.0-18.0) 5$ & 13.2 & $(11.0-21.0) 4$ \\
\hline Forearm length & $(42.0-49.0) 7$ & 41.4 & (42.9-51.0) 17 \\
\hline Condylocanine length & $(13.4-14.4) 3$ & 13.6 & (13.5-15.7) 11 \\
\hline Basisphenoid pit length & $(1.8-2.0) 5$ & 2.0 & $(1.8-2.2) 10$ \\
\hline Interorbital length & $(2.9-3.4) 5$ & 3.7 & $(2.9-3.5) 10$ \\
\hline Lacrimal breadth & $(6.3-6.8) 5$ & 5.8 & $(6.0-7.1) 7$ \\
\hline Zygomatic breadth & (9.1-9.7) 3 & 8.6 & $(8.7-10.2) 12$ \\
\hline Mastoid breadth & $(7.4-7.8) 3$ & 7.3 & $(7.3-8.0) 6$ \\
\hline Maxillary toothrow length & $(5.7-6.6) 6$ & 6.1 & $(5.7-7.1) 12$ \\
\hline Breadth across molars & $(6.5-7.6) 6$ & 6.7 & $(6.5-7.5) 12$ \\
\hline Lower molar row length & $(3.8-4.3) 5$ & 3.9 & $(3.6-4.4) 12$ \\
\hline
\end{tabular}

rosenbergi (Thomas, 1897); Artibeus phaeotis (Miller, 1902); Carollia brevicauda (Schinz, 1821); Carollia castanea Allen, 1890; Carollia perspicillata (Linnaeus, 1758); Choeroniscus periosus Handley 1966; Lonchophylla robusta Miller, 1912; Rhinophylla alethina Handley, 1966; Vampyressa thyone Thomas, 1909; and Vampyriscus nymphaea (Thomas, 1909).

Our specimen ( $\mathrm{CMCH}$ 987) despite being slightly damaged, with parts of the left zygomatic arch and coronoid process broken, exhibits all the diagnostic characteristics of the species. The external and craniodental measurements of our specimen fall within the range of size variation previously documented for the species (Table 1). The localities where $C$. centralis has been recorded throughout its distribution are listed in the Appendix and mapped in Fig. 2.

\section{DISCUSSION}

Despite their wide distributional range, both species of Centronycteris are known only by a few records (Simmons \& Handley 1998, Rodríguez-Posada 2016). Because of this, all aspects of their natural history are also poorly known. In Colombia, C. centralis has been reported for the Pacific and Caribbean regions, as well as in valleys between the Central and Oriental Cordilleras (Fig. 2). Several records of the species have been reported for the Pacific region in Ecuador, but only one has been reported for this region in Colombia (Supplementary Material and Fig. 2). Our record fills a distributional gap in the Pacific region between the Valle del Cauca (Fig. 2 [29]) and the Darién (Fig. 2 [19]) records. The closest previous report to our record (Fig. 2 [25]) is the record from El Carmen de Viboral in the department of Antioquia (Fig. 2 [22]; $155 \mathrm{~km}$ ). The other record from the Pacific region of Colombia, Río Anchicayá in the department of Valle del Cauca, is $231 \mathrm{~km}$ away from our Chocó record (Fig. 2).
Centronycteris centralis currently presents a disjunct distribution that may suggest the lack of gene flow between the populations from Central America and western and northern Colombia with the ones occurring east of the Andes in Ecuador and Peru (Fig. 2). This pattern raises the possibility that these two groups could be different species or that more effort is needed to record this species east of the Andes in Colombia. In general, due to the lack of knowledge and the low number of captures, there is a need to evaluate the systematics of the genus using molecular data.

The low representativeness of bats of this genus in natural history collections is due to the difficulty of capturing them by traditional methods (e.g., ground level mist nets). This is due to their ability to detect mist nets and due to their foraging behavior. These bats forage mostly in the canopy well above the placement of the mist nets. This highlights the need for the inclusion of acoustic methods to detect the presence of these bats.

Although being known by few records across its distribution, IUCN categorized C. centralis as Least Concern (LC) (Arroyo-Cabrales et al. 2015). Our record from the Chocó was collected within the newly created "A-CO-001 Pacurita Chocó-Central" an AICOM's (Área de Importancia para la Conservación de Murciélagos) with an area of 143,889 km². Forty percent of the known bat diversity of the department of Chocó, two endemic species (Rhinophylla alethina and Choeroniscus periosus) of the Choco biogeographic region, and the uncommon Lionycteris spurrelli have been recorded in this AICOM.

\section{ACKNOWLEDGEMENTS}

We would like to thank the staff of the Colección Teriológica del Chocó (ColTerChocó) for allowing us access 
to study the specimen, Luis Beltran (Guachene) and the comunidad de Pacurita (Quibdó) for their hospitality during the fieldwork duration.

\section{REFERENCES}

ALBUJA, L. (1999). Murciélagos del Ecuador. 2da edición. ed.: Cicetronic Cía. Ltda. Offset. Quito, Ecuador, 288 pp.

ALLEN, G. M. \& BARBOUR, T. (1923). Mammals from Darien. Bulletin of the Museum of Comparative Zoology, 65: 259274.

ARITA, H. T. (1993). Rarity in Neotropical bats: correlations with phylogeny, diet, and body mass. Ecological Applications, 3(3): 506-517. https://doi.org/10.2307/1941919

ARROYO-CABRALES, J., MILLER, B., REID, F., CUARÓN, A. D. \& DE GRAMMONT, P. C. (2015). Centronycteris centralis. The IUCN Red List of Threatened Species 2015: e.T136350A22023809. Downloaded: 04 June 2019. https://doi.org/10.2305/IUCN.UK.2015-4.RLTS. T136350A22023809.en

BAKER, R. J. \& JONES, J. K. (1975). Additional records of bats from Nicaragua, with a revised checklist of Chiroptera. The Museum, Texas Tech University, 32: 1-13. https:// doi.org/10.5962/bhl.title.142873

CASTAÑO, J. H. \& CORRALES, J. D. (2007). Primer registro de Centronycteris centralis (Chiroptera: Emballonuridae) en los Andes colombianos. Mastozoología Neotropical, 14(1): 69-72.

DALQUEST, W. W., FRUM, W. G. \& HALL, E. R. (1950). A northern record for Centronycteris maximiliani centralis, with a key to the skulls of North American Emballonurine bats. Anales del Instituto de Biología, 21(2): 431-433.

GREENBAUM, I. F. \& JONES, J. K. (1978). Noteworthy records of bats from El Salvador, Honduras, and Nicaragua. The Museum, Texas Tech University., 55: 1-7. https://doi. org/10.5962/bhl.title.142888

HANDLEY, C. O. (1966). Checklist of the mammals of Panama. In: Ectoparasites of Panama. ed.: Field Museum of Natural History. Chicago, Illinois, United States of America, p.753-795.

HICE, C. L. \& SOLARI, S. (2002). First record of Centronycteris maximiliani (Fischer, 1829) and two additional records of C. centralis Thomas, 1912 from Peru. Acta Chiropterologica, 4(2): 217-220. https://doi. org/10.3161/001.004.0209

HOOD, C. S. \& GARDNER, A. L. (2008). Family Emballonuridae Gervais, 1856. In: Mammals of South America, vol. 1: Marsupials, xenarthrans, shrews, and bats. ed.: University of Chicago Press. Chicago, Illinois, United States of America, p.188-207.

LAVAL, R. K. (1977). Notes on some Costa Rican bats. Brenesia, 10/11: 77-83.

MANTILLA-MELUK, H., RAMÍREZ-CHAVES, H. E., JIMÉNEZORTEGA, A. M. \& RODRÍGUEZ-POSADA, M. E. (2014). Emballonurid bats from Colombia: annotated checklist, distribution, and biogeography. THERYA, 5(1): 229-255. https://doi.org/10.12933/therya-14-189
QUINTO-MOSQUERA, H., HURATDO, F. M., MORENO, H. Y. C. \& PEREZ LUIS, M. T. Y. (2016). Biomasa de raíces finas y fertilidad del suelo en bosques pluviales tropicales del pacífico colombiano. Colombia Forestal, 19(1): 53 67. https://doi.org/10.14483/udistrital.jour.colomb. for.2016.1.a04

REID, F. A. (2009). A field guide to the mammals of Central America and southeast Mexico. 2nd edition. ed.: Oxford University Press. New York, United States of America, $384 \mathrm{pp}$.

RODRÍGUEZ-POSADA, M. E. (2016). Confirmación de la presencia de Centronycteris maximiliani (Chiroptera: Emballonuridae) en Colombia, con comentarios sobre la distribución de Centronycteris. Mastozoología Neotropical, 23(1): 179-184.

SANBORN, C. C. (1936). Records and measurements of Neotropical bats. Field Mus. Nat. Hist. Zool. Ser., 20(13): 93-105.

SANBORN, C. C. (1937). American bats of the subfamily Emballonurinae. Field Mus. Nat. Hist. Zool. Ser., 20(24): 321-354. https://doi.org/10.5962/bhl.title.3225

SANBORN, C. C. (1941). Descriptions and records of Neotropical bats. Papers on Mammalogy, Field Mus. Nat. Hist. Zool. Ser., 27: 371-387.

SIKES, R. S. \& THE ANIMAL CARE AND USE COMMITTEE OF THE AMERICAN SOCIETY OF MAMMALOGISTS. (2016). 2016 Guidelines of the American Society of Mammalogists for the use of wild mammals in research and education. Journal of Mammalogy, 97(3): 663-688. https://doi.org/10.1093/jmammal/gyw078

SIMMONS, N. B. \& HANDLEY, C. O. (1998). A revision of Centronycteris Gray (Chiroptera, Emballonuridae) with notes on natural history. American Museum Novitates, 3239: 1-28.

STARRETT, A. \& CASEBEER, R. S. (1968). Records of bats from Costa Rica. Contributions in Sciencie (Los Angeles), 148: $1-21$.

THOMAS, O. (1912). LXXX. - New Centronycteris and Ctenomys from S. America. Annals and Magazine of Natural History, 10/60: 638-640. https://doi. org/10.1080/00222931208693286

TIRIRA, D. G. (1999). Mamíferos del Ecuador. Publicación especial 1. 1ra edición. ed.: Museo de Zoología \& Pontificia Universidad Católica del Ecuador/SIMBIOE. Quito, Ecuador, 392 pp.

TIRIRA, D. G. (2008). Mamíferos de los bosques húmedos del noroccidente de Ecuador. Publicación especial sobre los mamíferos de Ecuador 7. ed.: Ediciones Murciélago Blanco. Quito, Ecuador, 348 pp.

WOODMAN, N. (2003). New record of the rare emballonurid bat Centronycteris centralis Thomas, 1912 in Costa Rica, with notes on feeding habits. Caribbean Journal of Science, 39(3): 399-402. 